\title{
PERLINDUNGAN HUKUM TERHADAP ANAK KORBAN KEKERASAN SEKSUAL
}

\section{LEGAL PROTECTION OF CHILD VICTIMS OF SEXUAL VIOLENCE}

\author{
Ni Putu Rai Yuliartini*, Dewa Gede Sudika Mangku \\ Program Studi Ilmu Hukum Universitas Pendidikan Ganesha \\ Jalan Udayana Nomor 11 Bali 81116, Indonesia
}

\section{INFO ARTIKEL}

\section{Riwayat Artikel:}

Diterima : 11 Oktober 2020

Disetujui : 26 Desember 2021

\section{Keywords:}

legal protection, children, victims of sexual violence

\section{Kata Kunci:}

perlindungan hukum, anak, korban kekerasan seksual

\section{*) Korespondensi:}

E-mail: raiyuliartini@undiksha.ac.id

\begin{abstract}
: this study aimed to analyze the implementation of legal protection for child victims of sexual violence in Singaraja City and the efforts of law enforcement officials in reducing the number of sexual violence in Singaraja City. This study used an empirical legal research approach with a descriptive type. Sources of data were obtained from primary data and secondary data. Data collection techniques through observation, interviews, and documentation studies. Determining the sample uses a non-probability sampling technique called purposive sampling. The data is processed and analyzed qualitatively. The results study indicated that the implementation of legal protection for child victims of sexual violence in Singaraja City had not run optimally. Some several facilities and services had not been fulfilled. The Buleleng Police took preemptive, preventive, and repressive measures to reduce the number of sexual violence in Singaraja City. The Social Service of Buleleng Regency assisted in assistance, trauma recovery, and counseling services for children who were victims of social violence.
\end{abstract}

\begin{abstract}
Abstrak: kajian ini bertujuan untuk menganalisis implementasi perlindungan hukum terhadap anak korban kekerasan seksual di Kota Singaraja dan upaya aparat penegak hukum dalam menurunkan angka kekerasan seksual di Kota Singaraja. Kajian ini menggunakan pendekatan penelitian hukum empiris dengan jenis deskriptif. Sumber data diperoleh dari data primer dan data sekunder. Teknik pengumpulan data melalui observasi, wawancara, dan studi dokumentasi. Teknik penentuan sampel menggunakan teknik non probability sampling dengan bentuk purposive sampling. Data diolah dan dianalisis secara kualitatif. Hasil kajian ini menunjukkan bahwa implementasi perlindungan hukum terhadap anak korban kekerasan seksual di Kota Singaraja belum berjalan optimal karena ada beberapa fasilitas dan pelayanan yang belum terpenuhi. Polres Buleleng melakukan tindakan preemtif, preventif, dan represif dalam rangka menurunkan angka kekerasan seksual di Kota Singaraja. Dinas Sosial Kabupaten Buleleng memberikan bantuan berupa pendampingan, memulihkan trauma, dan pelayanan konseling kepada anak korban kekerasan sosial.
\end{abstract}

\section{PENDAHULUAN}

Anak merupakan amanah sekaligus karunia Tuhan Yang Maha Esa. Anak dianggap sebagai harta kekayaan yang paling berharga dibandingkan dengan harta benda lainnya. Setiap anak mempunyai hak asasi yang diatur dalam UndangUndang Dasar Negara Republik Indonesia Tahun
1945 dan konvensi Perserikatan Bangsa-Bangsa tentang Hak-Hak Anak (Haling dkk., 2018). Anak sebagai generasi penerus cita-cita bangsa mempunyai hak atas kelangsungan hidup, tumbuh dan berkembang, berpartisipasi, perlindungan dari tindak kekerasan dan diskriminasi, serta hak sipil dan kebebasan (Rizqian, 2021). Hak 
asasi anak tidak dapat dilepaskan dari peran pemerintah sebagai penanggung jawab dalam menjamin kesejahteraan anak.

Anak merupakan individu yang belum matang baik secara fisik, mental dan sosialnya. Anak merupakan kelompok yang lemah dan rentan sehingga lebih berisiko menjadi dampak kekerasan seksual (Nashriana, 2011). Kekerasan seksual terhadap anak di bawah umur berdampak pada psikologis dan pertumbuhan anak. Dampak psikologis terhadap anak korban kekerasan seksual dapat menyebabkan trauma yang berkepanjangan, rasa takut yang berlebihan, perkembangan jiwa yang terganggu, dan keterbelakangan mental (Yusyanti, 2020). Dampak psikologis dapat menjadi suatu ancaman buruk bagi anak korban kekerasan seksual.

Anak korban kekerasan seksual harus mendapatkan perhatian serius baik dari keluarga dan pemerintah. Korban kekerasan seksual juga memerlukan perlindungan agar hak-haknya dapat terpenuhi (Jamaludin, 2021). Kekerasan seksual pada anak berkaitan dengan eksploitasi, perlakuan salah, diskriminasi dan lain sebagainya. Anak sangat perlu dilindungi dari berbagai bentuk kejahatan yang dapat memengaruhi perkembangan fisik, mental, serta rohaninya (Rini, 2020). Anak korban kekerasan seksual harus mendapatkan pemulihan kondisi traumatik agar tidak menjadi pelaku di kemudian hari (Lubis, 2017). Oleh karena itu, diperlukan adanya peraturan yang dapat melindungi anak dari berbagai bentuk kejahatan.

Perlindungan hukum terhadap kekerasan seksual pada anak diatur dalam Undang-Undang Nomor 35 Tahun 2014 tentang Perubahan atas Undang-Undang Nomor 23 Tahun 2002 tentang Perlindungan Anak. Pasal 15 huruf f UndangUndang Nomor 35 Tahun 2014 menjelaskan bahwa setiap anak berhak untuk memperoleh perlindungan dari kejahatan seksual. Pasal 21 sampai Pasal 26 menjelaskan bahwa negara, pemerintah, masyarakat, keluarga, dan orang tua atau wali berperan dalam penyelenggaraan perlindungan anak. Larangan melakukan tindakan kekerasan seksual pada anak diatur dalam Pasal 76 huruf d yang menjelaskan bahwa setiap orang dilarang melakukan kekerasan atau memberikan ancaman kepada anak. Pasal 76 huruf e juga menjelaskan bahwa setiap orang dilarang melakukan kekerasan memaksa, melakukan tipu muslihat, melakukan serangkaian kebohongan, atau membujuk anak untuk melakukan perbuatan asusila.

Kekerasan seksual pada anak juga diatur dalam Kitab Undang-Undang Hukum Pidana (KUHP), Undang-Undang Nomor 17 Tahun 2016 tentang Penetapan Peraturan Pemerintah Pengganti Undang-Undang Nomor 1 Tahun 2016 tentang Perubahan Kedua atas Undang-Undang Nomor 3 Tahun 2002 tentang Perlindungan Anak, Undang-Undang Nomor 23 Tahun 2004 tentang Penghapusan Kekerasan dalam Rumah Tangga (KDRT), Undang-Undang Nomor 11 Tahun 2012 tentang Sistem Peradilan Pidana Anak, dan Peraturan Pemerintah Nomor 70 Tahun 2020 tentang Tata Cara Pelaksanaan Tindakan Kebiri Kimia, Pemasangan Alat Pendeteksi Elektronik, Rehabilitasi dan Pengumuman Identitas Pelaku Kekerasan Seksual terhadap Anak. Perlindungan dari tindak kekerasan seksual terhadap anak di Indonesia bertujuan agar anak dapat tumbuh dan berkembang secara optimal.

Peraturan perundang-undangan yang mengatur perlindungan hukum terhadap anak tidak mengurangi terjadinya permasalahan kekerasan seksual di Indonesia. Kekerasan seksual pada anak masih banyak terjadi di berbagai tempat baik di kota dan di desa. Kekerasan seksual yang menimpa anak-anak di Indonesia bukan saja terjadi di wilayah-wilayah yang rawan kekerasan, tetapi juga terjadi di lingkungan keluarga dan sekolah. Pelaku kekerasan seksual terhadap anak juga tidak hanya dilakukan oleh orang lain yang tidak dikenali, tetapi juga dilakukan oleh orang-orang yang dikenali, dekat, dan dipercaya oleh anak (Tuliah, 2018). Kekerasan seksual mengancam keselamatan anak-anak di Indonesia yang berada di posisi sangat rentan di hampir semua wilayah sosial.

Tingginya kasus kekerasan seksual pada anak menggambarkan rendahnya perhatian pemerintah. Tantangan yang dihadapi dalam melakukan perlindungan dari tindakan kekerasan terhadap anak di Indonesia adalah mewujudkan pemenuhan hak anak dan menjauhkan anak dari ancaman perampasan dalam waktu bersamaan (Wijaya \& Ananta, 2016). Kekerasan seksual terhadap anak merupakan pelanggaran hak asasi manusia berat. Kekerasan seksual pada anak harus ditempatkan sebagai kejahatan luar biasa (extraordinary crime) karena kerusakan yang disebabkan telah mengancam masa depan generasi bangsa (Waluyo, 2012). Kekerasan 
seksual terhadap anak telah merusak masa depan negara.

Perkembangan pikiran dan sifat manusia menjadi tantangan pada zaman modern saat ini. Perkembangan fisik, pikiran atau sifat manusia ada yang menuju ke arah positif dan negatif. Pikiran dan sifat negatif manusia yang sangat memprihatinkan dapat mengakibatkan terjadinya tindakan kekerasan seksual kepada anak (Yuliartini, 2014). Kekerasan seksual terhadap anak merupakan suatu perilaku yang sangat tidak manusiawi (Sommaliagustina \& Sari, 2018). Anak adalah manusia yang memiliki keterbatasan dan harus mendapatkan perlindungan dari semua elemen masyarakat dan hukum yang berlaku.

Deputi Bidang Perlindungan Anak Kementerian Pemberdayaan Perempuan dan Perlindungan Anak (Kemen PPPA) mengungkapkan bahwa sejak Januari hingga 31 Juli Tahun 2020 tercatat ada 4.116 kasus kekerasan pada anak di Indonesia. Ada 2.556 korban kekerasan seksual, 1.111 korban kekerasan fisik, dan 979 korban kekerasan psikis (Kemen PPPA, 2020). Kekerasan seksual pada anak menjadi suatu permasalahan yang cukup serius dan mengancam masa depan bangsa. Anak korban kekerasan seksual akan menerima dampak secara fisik dan psikisnya. Permasalahan kekerasan seksual pada anak juga memberikan dampak bagi masyarakat. Kasus kekerasan seksual pada anak menunjukkan bahwa pemenuhan hak anak atas perlindungan dari kekerasan belum berjalan sebagaimana mestinya.

Rendahnya kualitas perlindungan anak di Indonesia banyak menuai kritik dari berbagai elemen masyarakat. Tugas pemerintah seharusnya berupaya memberikan perlindungan hukum kepada anak untuk dapat memperoleh jaminan atas kelangsungan hidup dan penghidupannya sebagai bagian dari hak asasi manusia (Mansur \& Gultom, 2007). Anak juga memiliki eksistensi dalam kehidupan dan kemanusiaan, tetapi hakhak yang dimiliki oleh anak belum sepenuhnya terpenuhi. Anak-anak pada kenyataannya masih terus tereksploitasi baik secara ekonomi menjadi pekerja anak, anak jalanan, atau eksploitasi seksual (Harahap, 2016). Kesadaran masyarakat dan aparat penegak hukum sangat dibutuhkan dalam melindungi hak anak.

Kekerasan seksual menjadi lebih sulit untuk ditangani dan diuangkap karena korban tidak konsisten memperjuangkan haknya dalam peradilan. Aspek kekerasan seksual selalu dikaitkan dengan wacana moralitas sehingga yang dilakukan korban akan selalu terlihat salah dan kurang waspada. Dampak terjadinya kekerasan seksual terhadap anak diperparah dengan adanya budaya victim blaming yang menempatkan posisi korban ikut bertanggung jawab atas semua yang terjadi pada dirinya (Wulandari \& Krisnani, 2020). Kekerasan seksual dapat merugikan korban dalam mendapatkan keadilan di depan hukum karena intimidasi moral yang diterima.

Kasus kekerasan seksual yang dianalisis dalam kajian ini yaitu kasus yang terjadi di Kota Singaraja yang merupakan bagian dari Wilayah Hukum Polres Buleleng. Berdasarkan data Kepolisian Negara Republik Indonesia Daerah Bali Resor Buleleng bahwa terjadi peningkatan kekerasan seksual dari tahun ke tahun. Data kekerasan seksual pada anak yang sudah ditindak atau diproses lima tahun terakhir, yaitu pada tahun 2016 ada 15 kasus, tahun 2017 ada 25 kasus, tahun 2018 ada 29 kasus, tahun 2019 ada 32 kasus dan tahun 2020 ada 14 kasus. Hal ini menunjukkan bahwa terjadi fluktuasi jumlah kasus kekerasan seksual terhadap anak dalam lima tahun terakhir yaitu sejak tahun 2016 sampai tahun 2020. Peningkatan jumlah kasus kekerasan seksual tertinggi terjadi pada tahun 2019. Adanya fluktuasi jumlah kekerasan seksual dipengaruhi oleh faktor-faktor tertentu, baik dari kesadaran hukum masyarakat atau dari segi optimalisasi penegakan hukumnya.

Kasus kekerasan seksual terhadap anak yang terjadi di Singaraja Bali pada tahun 2020, yaitu seorang korban KMW berusia 12 tahun dilecehkan secara seksual oleh belasan orang. Pelecehan seksual yang terjadi tidak hanya dilakukan pacarnya, tetapi juga teman-teman pacarnya. Mirisnya dari total sepuluh pelaku yang melakukan perbuatan tidak bermoral terhadap KMW secara bergantian, tujuh orang diantaranya masih berusia berkisar antara 15 tahun sampai dengan 17 tahun. Kasus kekerasan seksual terhadap korban KMW mengakibatkan terganggunya ketenangan dan kedamaian masyarakat yang berujung pada ketimpangan dan disharmoni sosial. Dampak yang ditimbulkan dari kasus kekerasan seksual tidak hanya menimpa korbannya, tetapi juga berimplikasi kepada ketakutan pada masyarakat. 
Fakta mengenai banyaknya kasus kekerasan seksual yang menimpa anak khususnya di Kota Singaraja telah mengindikasikan bahwa anak belum mendapat perhatian, perlindungan, serta terabaikan keberadaanya. Kedudukan anak dianggap kurang menguntungkan dan dikualifikasikan sebagai kelompok rentan atau lemah. Upaya menghentikan kekerasan seksual merupakan hal penting, karena korban kekerasan seksual dapat mengalami trauma yang berkepanjangan, perasaan malu, dan ketakutan. Peraturan perundang-undangan dan perhatian pemerintah sangat dibutuhkan dalam mengakomodasi hak asasi anak (Gultom, 2013). Pemerintah harus melakukan terobosan atas upaya penghapusan segala bentuk kekerasan seksual terhadap anak-anak di Indonesia.

Perlindungan hukum terhadap anak korban kekerasan seksual merupakan masalah yang serius. Permasalahan kekerasan seksual kepada anak tidak dibebankan kepada satu pihak saja, tetapi perlu adanya sinergitas kerjasama antara orang tua, aparat penegak hukum, serta masyarakat (Prema, Ruba'i, \& Aprilianda, 2021). Permasalahan kekerasan seksual membutuhkan upaya penanggulangan melalui sarana penal atau non penal, sehingga dapat menjamin perlindungan hukum terhadap anak dan menurunkan angka kekerasan seksual terhadap anak. Berdasarkan permasalahan yang telah diuraikan, kajian ini membahas mengenai implementasi perlindungan hukum terhadap anak korban kekerasan seksual di Kota Singaraja dan upaya aparat penegak hukum dalam menurunkan angka kekerasan seksual di Kota Singaraja.

\section{METODE}

Pendekatan penelitian yang digunakan dalam kajian ini yaitu pendekatan hukum empiris. Pendekatan hukum empiris memandang hukum sebagai kenyataan sosial, budaya, dan lain-lain (Ali \& Heryani, 2012). Jenis penelitian dalam kajian ini menggunakan jenis deskriptif yang bertujuan untuk mendeskripsikan perlindungan hukum terhadap anak korban kekerasan seksual di Kota Singaraja. Sumber data yang digunakan dalam kajian ini berupa data primer dan data sekunder. Data primer adalah data yang dikumpulkan langsung dengan menggali informasi di lapangan, sedangkan data sekunder diperoleh dari studi kepustakaan melalui media tertulis dan media elektronik (Sunggono, 2006).
Teknik pengumpulan data yang digunakan yaitu teknik observasi, wawancara, dan studi dokumentasi kepada Dinas Sosial Kabupaten Buleleng, Polres Buleleng, serta Pusat Pelayanan Terpadu Perlindungan Anak dan Pemberdayaan Perempuan Kabupaten Buleleng. Kajian ini menggunakan teknik penentuan sampel non probability sampling yang berbentuk purposive sampling, kemudian semua data diolah dan dianalisis secara kualitatif.

\section{HASIL DAN PEMBAHASAN}

\section{Implementasi Perlindungan Hukum terhadap Anak Korban Kekerasan Seksual di Kota Singaraja}

Anak merupakan generasi penerus bangsa yang membutuhkan perlindungan hukum khusus karena alasan fisik dan mental yang belum dewasa dan matang. Hak asasi anak termasuk dalam hak asasi manusia yang sangat dijunjung tinggi di Indonesia (Sommaliagustina \& Sari, 2018). Hak asasi anak di Indonesia ditandai dengan adanya jaminan perlindungan dan pemenuhan hak anak dalam Undang-Undang Dasar Negara Republik Indonesia Tahun 1945 dan beberapa peraturan perundang-undangan. Hak anak sebagai bagian dari hak asasi manusia wajib dilindungi oleh orang tua, keluarga, masyarakat, pemerintah, dan negara.

Perlindungan hukum bagi anak korban kekerasan seksual bertujuan untuk mewujudkan hak asasi anak. Perlindungan hukum terhadap anak merupakan upaya memberikan kebebasan hak asasi anak (fundamental rights and freedom of children), serta kepentingan yang berhubungan dengan kesejahteraan anak (Yusyanti, 2020). Perlindungan hukum terhadap anak korban kekerasan seksual yang telah diamanatkan dalam undang-undang tidak hanya menjadi tanggung jawab sepihak saja. Perlindungan hukum terhadap anak menjadi tanggung jawab semua pihak tanpa terkecuali.

Peraturan perundang-undangan terkait kekerasan seksual kepada anak telah diatur dalam Undang-Undang Nomor 35 Tahun 2014 tentang Perubahan Atas Undang-Undang Nomor 23 Tahun 2002 tentang Perlindungan Anak, Kitab Undang-Undang Hukum Pidana (KUHP), Undang-Undang Nomor 17 Tahun 2016 tentang Penetapan Peraturan Pemerintah Pengganti Undang-Undang Nomor 1 Tahun 2016 
tentang Perubahan Kedua atas Undang-Undang Nomor 3 Tahun 2002 tentang Perlindungan Anak, Undang-Undang Nomor 11 Tahun 2012 tentang Sistem Peradilan Pidana Anak, dan Peraturan Pemerintah Nomor 70 Tahun 2020 tentang Tata Cara Pelaksanaan Tindakan Kebiri Kimia, Pemasangan Alat Pendeteksi Elektronik, Rehabilitasi dan Pengumuman Identitas Pelaku Kekerasan Seksual.

Regulasi yang dikeluarkan oleh pemerintah pusat belum cukup untuk mengatur perlindungan hukum terhadap anak korban kekerasan seksual. Oleh karena itu, diperlukan juga regulasi atau aturan pada tingkat daerah untuk melindungi anak korban kekerasan seksual (Gultom, 2013). Kota Singaraja menjadi salah satu kota dengan kasus kekerasan seksual yang tinggi. Kota Singaraja yang dikenal dengan kota pendidikan dan ramah anak memerlukan suatu aturan yang digunakan untuk melindungi anak dari masalah kekerasan seksual. Regulasi mengenai kekerasan seksual di Kota Singaraja diatur pada Peraturan Daerah (Perda) Kabupaten Buleleng Nomor 5 Tahun 2019 tentang Perlindungan Perempuan dan Anak dari Tindak Kekerasan.

Pasal 5 huruf b Perda Kabupaten Buleleng Nomor 5 Tahun 2019 tentang Perlindungan Perempuan dan Anak dari Tindak Kekerasan menjelaskan bahwa pemerintah daerah bertanggung jawab dalam melindungi perempuan dan anak dari perbuatan dalam bentuk tindak kekerasan seksual. Pelayanan terpadu bagi korban tindak kekerasan diatur pada Pasal 11 ayat (1) bahwa pemerintah daerah melaksanakan pelayanan terpadu bagi korban tindak kekerasan melalui kegiatan pelayanan pengaduan, pelayanan kesehatan, konseling, bimbingan rohani, pelayanan rehabilitasi sosial, pelayanan bantuan, pendampingan hukum, serta pemulangan dan reintegrasi. Pasal 11 ayat (2) huruf c juga menjelaskan bahwa pelayanan terpadu bagi korban kekerasan seksual didukung dengan fasilitas berupa pusat pelayanan dan rumah aman.

Pelaksanaan Perda Kabupaten Buleleng Nomor 5 Tahun 2019 tentang Perlindungan Perempuan dan Anak dari Tindak Kekerasan belum berjalan optimal karena ada beberapa fasilitas dan pelayanan yang belum terpenuhi. Kendala yang dihadapi dalam pelaksanaan Perda Kabupaten Buleleng yaitu belum tersedianya pelayanan fasilitas rumah aman bagi anak korban kekerasan seksual. Rumah aman merupakan tempat tinggal sementara bagi perempuan dan anak korban kekerasan yang membutuhkan perlindungan. Belum tersedianya rumah aman bagi anak korban kekerasan seksual menjadi kendala dalam memberikan pengawasan dan pendampingan konseling untuk memulihkan trauma psikologis korban. Beberapa aturan atau regulasi mengenai kekerasan seksual terhadap anak masih perlu dievaluasi pelaksanaannya.

\section{Upaya Aparat Penegak Hukum dalam Menurunkan Angka Kekerasan Seksual di Kota Singaraja}

Kekerasan seksual pada anak menjadi suatu permasalahan yang cukup serius dan mengancam masa depan bangsa. Kekerasan seksual terhadap anak bisa dilakukan oleh semua pihak dari berbagai golongan (Tuliah, 2018). Pelaku kekerasan seksual terhadap anak bisa dilakukan oleh orang yang terdekat dengan anak. Kekerasan seksual terhadap anak menyebabkan trauma yang berkelanjutan, perasaan malu, ketakutan sehingga dapat merusak masa depan anak-anak di Indonesia (Rini, 2020). Pemerintah berperan penting dalam mengatasi masalah kekerasan seksual terhadap anak (Rizqian, 2021). Permasalahan kekerasan seksual pada anak merupakan masalah serius yang terus mengalami peningkatan dari tahun ke tahun terutama di Kota Singaraja.

Pihak kepolisian dan Dinas Sosial Kabupaten Buleleng melakukan berbagai upaya penanggulangan untuk mengantisipasi dan menekan angka kekerasan seksual terhadap anak di Kota Singaraja. Upaya perlindungan hukum yang dilakukan oleh pihak Polres Buleleng dalam mencegah perkembangan kasus kekerasan seksual meliputi upaya preemtif, preventif, dan represif. Upaya preemtif dilakukan dengan melaksanakan sosialisasi dan penyuluhan kepada anak-anak dan orang tua mengenai pentingnya pendidikan seks sejak dini, dampak dari pergaulan bebas dan dampak kekerasan seksual. Sosialisasi yang dilakukan bertujuan agar segala bentuk kekerasan seksual tidak dapat terjadi (Haling dkk., 2018). Pihak kepolisian juga bekerja sama dengan Pusat Pelayanan Terpadu Perlindungan Anak dan Pemberdayaan Perempuan (P2TP2A) untuk melakukan sosialisasi ke sekolah-sekolah dan masyarakat tentang seksualitas atau kejahatankejahatan seksual terhadap anak serta pengaturan dan sanksinya. 
Upaya preventif yang dilakukan oleh Polres Buleleng sebagai upaya lanjutan untuk menghilangkan kesempatan dilakukannya suatu kejahatan. Upaya preventif adalah penanggulangan kejahatan yang dilakukan dengan cara menghilangkan faktor-faktor penyebab terjadinya tindak kekerasan seksual (Lubis, 2017). Faktor penyebab terjadinya kekerasan seksual pada anak di Kota Singaraja yaitu perkembangan teknologi. Oleh karena itu, Polres Buleleng melakukan pencegahan peredaran konten pornografi dengan mengajak masyarakat, anak-anak, dan orang tua untuk bersama-sama melaporkan jika ditemukan halhal berbau pornografi.

Upaya represif yang dilakukan oleh Polres Buleleng yaitu menindak pelaku sesuai hukum yang berlaku. Upaya represif adalah upaya yang dilakukan setelah terjadinya tindak pidana berupa penegakan hukum (law enforcement) dengan menjatuhkan hukuman kepada pelaku (Yusyanti, 2020). Upaya represif bertujuan untuk merubah perbuatan pelaku serta memperbaikinya agar tidak mengulanginya lagi. Upaya represif disebut sebagai upaya penal atau upaya terakhir (ultimum remedium) dengan memberikan sanksi yang telah diatur dalam hukum pidana (Jamludin, 2021). Pihak kepolisian harus cepat dan tanggap menerima laporan terkait kekerasan seksual terhadap anak. Pihak kepolisian melakukan penyelidikan dan penyidikan dengan memeriksa terdakwa, korban beserta bukti dan para saksi, serta membuat BAP yang diserahkan ke kejaksaan untuk disidangkan di pengadilan.

Data yang diperoleh dari Dinas Sosial Kabupaten Buleleng terkait jumlah anak yang memerlukan perlindungan khusus (AMPK) dalam kurun waktu tiga tahun terakhir yaitu Tahun 2018 sejumlah 5 anak mengalami pemerkosaan dan 9 pencabulan, tahun 2019 sejumlah 22 anak mengalami pemerkosaan dan 6 pencabulan, dan tahun 2020 sejumlah 10 anak mengalami pemerkosaan dan 2 pencabulan. Berdasarkan data AMPK menunjukkan terjadi peningkatan dalam tiga tahun terakhir. Peningkatan jumlah kasus pemerkosaan tertinggi terjadi pada tahun 2019. Anak yang memerlukan perlindungan terkait kasus pencabulan mengalami penurunan dari tahun 2018 sampai 2020.

Dinas Sosial Kabupaten Buleleng juga melakukan beberapa upaya untuk menanggulangi kekerasan seksual terhadap anak. Upaya Dinas Sosial yang pertama adalah memberikan bantuan berupa pendampingan. Pendampingan merupakan salah satu bentuk pelayanan yang diberikan terhadap anak korban kekerasan seksual di Kota Singaraja. Tujuan pendampingan yang dilakukan oleh Dinas Sosial yaitu untuk menguatkan mental anak agar mampu menjalani prosedur dan proses pemulihan psikis terhadap tindak kekerasan yang sedang dialaminya (Harahap, 2016). Pendampingan yang diberikan oleh Dinas Sosial juga bertujuan untuk membantu dan menemai korban kekerasan seksual ke beberapa instansi.

Dinas Sosial Kabupaten Buleleng selanjutnya berupaya untuk memulihkan trauma anak korban kekerasan seksual. Setiap anak yang mengalami tindak kekerasan seksual merasakan trauma secara fisik maupun psikisnya (Haling dkk., 2018). Pemulihan trauma merupakan upaya yang dilakukan untuk menjauhkan anak dari pikiran dan perasaan yang terus membayangi (Sommaliagustina \& Sari, 2018). Upaya yang dilakukan oleh Dinas Sosial yaitu mengajak anak untuk bernyanyi bersama, bermain bersama, membuat kerajinan tangan dan menulis puisi. Pemulihan trauma bagi korban kekerasan seksual bertujuan agar anak tidak berdiam diri dengan mempunyai suatu kegiatan, sehingga anak dapat meminimalisir pikiran dan perasaan yang dapat membuat trauma.

Upaya terakhir yang dilakukan oleh Dinas Sosial Kabupaten Buleleng yaitu memberikan pelayanan konseling. Pelayanan konseling bertujuan untuk memberikan bantuan kepada anak korban kekerasan seksual yang mengalami depresi dan trauma (Lubis, 2017). Pelayanan konseling dilakukan dalam waktu 30 menit sampai 1 jam tergantung dari kondisi psikologis anak korban kekerasan seksual. Metode yang dilakukan untuk melakukan konseling kepada anak korban kekerasan seksual yaitu dengan cara melakukan pendekatan emosional (Yusyanti, 2020). Pendekatan emosional dilakukan karena kondisi dan emosi anak yang mudah berubah. Dinas Sosial dan Konselor harus melakukan pendekatan yang sesuai dengan kondisi anak korban kekerasan seksual (Jamaludin, 2021). Pendekatan dalam pelayanan konseling menjadi hal terpenting agar anak tidak cenderung menjadi pendiam dan sulit berinteraksi dengan orang lain. 


\section{SIMPULAN}

Perlindungan hukum terhadap anak korban kekerasan seksual di Kota Singaraja diatur dalam Peraturan Daerah Kabupaten Buleleng Nomor 5 Tahun 2019 tentang Perlindungan Perempuan dan Anak dari Tindak Kekerasan. Implementasi Perda Kabupaten Buleleng belum berjalan optimal karena ada beberapa fasilitas dan pelayanan untuk korban kekerasan seksual yang belum terpenuhi seperti tidak tersedianya rumah aman di Kota Singaraja. Upaya yang dilakukan oleh pihak Polres Buleleng untuk menurunkan angka kekerasan seksual di Kota Singaraja yaitu melakukan upaya preemtif dengan melaksanakan sosialisasi mengenai pentingnya pendidikan seks sejak dini, dampak dari pergaulan bebas serta dampak dari kekerasan seksual, upaya preventif dilakukan dengan mencegah peredaran konten pornografi, dan upaya represif yaitu menindak lanjuti pelaku sesuai hukum yang berlaku. Upaya yang dilakukan oleh Dinas Sosial Kabupaten Buleleng terdiri dari memberikan bantuan berupa pendampingan, memulihkan trauma, serta memberikan pelayanan konseling.

\section{DAFTAR RUJUKAN}

Ali, A., \& Heryani, W. (2012). Menjelajahi Kajian Empiris terhadap Hukum. Jakarta: Kencana Prenada Media Group.

Gultom, M. (2013). Perlindungan Hukum terhadap Anak dalam Sistem Peradilan Pidana Anak di Indonesia, Cetakan IV. Bandung: Refika Aditama.

Haling, S., Halim, P., Badruddin, S., \& Djanggih, H. (2018). Perlindungan Hak Asasi Anak Jalanan dalam Bidang Pendidikan menurut Hukum Nasional dan Konvensi Internasional. Jurnal Hukum dan Pembangunan, 48(2), 361-378.

Harahap, I. S. (2016). Perlindungan Hukum terhadap Anak Korban Kejahatan Seksual dalam Perspektif Hukum Progresif. Jurnal Media Hukum, 23(1), 37-47.

Jamaludin, A. (2021). Perlindungan Hukum Anak Korban Kekerasan Seksual. Jurnal CIC Lembaga Riset dan Konsultan Sosial, 3(2), 1-10.

Kementerian Pemberdayaan Perempuan dan Perlindungan Anak Republik Indonesia. (2020). Angka Kekerasan terhadap Anak di Masa Pandemi. Jakarta: Publikasi dan Media Kementerian Pemberdayaan Perempuan dan Perlindungan Anak.

Lubis, E. Z. (2017). Upaya Perlindungan Hukum terhadap Anak Korban Kekerasan Seksual. Jurnal Pendidikan Ilmu-Ilmu Sosial, 9(2), 141-150.

Mansur, D. A., \& Gultom, E. (2007). Urgensi Perlindungan Korban Kejahatan: Antara Norma dan Realita. Jakarta: Raja Grafindo Persada.

Nashriana. (2011). Perlindungan Hukum Pidana Bagi Anak di Indonesia. Jakarta: PT. Raja Grafindo Persada.

Prema, I. K. A., Ruba'i, M., \& Aprilianda, N. (2021). Pembatasan Usia Pertanggungjawaban Pidana Anak dalam Peraturan Perundang-Undangan. Jurnal Ilmiah Pendidikan Pancasila dan Kewarganegaraan, 4(2), 232-241.

Rini. (2020). Dampak Psikologis Jangka Panjang Kekerasan Seksual Anak (Komparasi Faktor: Pelaku, Tipe, Cara, Keterbukaan dan Dukungan Sosial). Jurnal IKRA-ITH Humaniora, 4(2), 156-167.

Rizqian, I. (2021). Upaya Perlindungan Hukum terhadap Anak sebagai Korban Tindak Pidana Kekerasan Seksual Dikaji menurut Hukum Pidana Indonesia. Journal Justiciabellen, 1(1), 51-61.

Republik Indonesia. (2019). Peraturan Daerah Kabupaten Buleleng Nomor 5 Tahun 2019 tentang Perlindungan Perempuan dan Anak dari Tindak Kekerasan. Lembaran Daerah Kabupaten Buleleng Tahun 2019 Nomor 5. Republik Indonesia. (2012). Undang-Undang Republik Indonesia Nomor 11 Tahun 2012 tentang Sistem Peradilan Pidana Anak. Lembaran Negara Republik Indonesia Tahun 2012 Nomor 153. Tambahan Lembaran Negara Republik Indonesia Nomor 5332. Republik Indonesia. (2014). Undang-Undang Nomor 35 Tahun 2014 tentang Perubahan atas Undang-Undang Nomor 23 Tahun 2002 tentang Perlindungan Anak. Lembaran Negara Republik Indonesia Tahun 2014 Nomor 297. Tambahan Lembaran Negara Republik Indonesia Nomor 5606.

Republik Indonesia. (2016). Undang-Undang Nomor 17 Tahun 2016 tentang Penetapan Peraturan Pemerintah Pengganti UndangUndang Nomor 1 Tahun 2016 tentang Perubahan Kedua atas Undang-Undang Nomor 3 Tahun 2002 tentang Perlindungan Anak. Lembaran Negara Republik Indonesia 
Tahun 2016 Nomor 237. Tambahan Lembaran

Negara Republik Indonesia Nomor 5946. Republik Indonesia. (2020). Peraturan Pemerintah

Nomor 70 Tahun 2020 tentang Tata Cara

Pelaksanaan Tindakan Kebiri Kimia, Pemasangan Alat Pendeteksi Elektronik, Rehabilitasi dan Pengumuman Identitas Pelaku Kekerasan Seksual. Lembaran Negara Republik Indonesia Tahun 2020 Nomor 269. Tambahan Lembaran Negara Republik Indonesia Nomor 6585.

Sommaliagustina, D., \& Sari, D. C. (2018). Kekerasan Seksual Pada Anak dalam Perspektif Hak Asasi Manusia. Jurnal Psikologi, 1(2), 76-85.

Sunggono, B. (2006). Metode Penelitian Hukum. Jakarta: PT. Raja Grafindo Persada.

Tuliah, S. (2018). Kajian Motif Pelaku Kekerasan Seksual terhadap Anak Melalui Modus Operandi di Lingkungan Keluarga. Jurnal
Sosiatri Sosiologi, 6(2), 1-17.

Waluyo, B. (2012). Viktimologi Perlindungan Korban dan Saksi. Jakarta: Sinar Grafika.

Wijaya, A., \& Ananta, W. P. (2016). Darurat Kejahatan Seksual. Malang: Sinar Grafika. Wulandari, E. P., \& Krisnani, H. (2020). Kecenderungan Menyalahkan Korban (Victim-Blaming) dalam Kekerasan Seksual terhadap Perempuan sebagai Dampak Kekeliruan Atribusi. Social Work Journal, 10(2), 187-197.

Yuliartini, N. P. (2014). Kajian Kriminologis Kenakalan Anak dalam Fenomena Balapan Liar di Kota Singaraja Bali. Denpasar: Program Studi Magister Hukum Universitas Udayana.

Yusyanti, D. (2020). Perlindungan Hukum terhadap Anak Korban dari Pelaku Tindak Pidana Kekerasan Seksual. Jurnal Penelitian Hukum, 20(4). 619-635. 